\title{
Persepsi Kemanfaatan dan Persepsi Kemudahan pada Minat Membayar PBB Menggunakan Go-Pay dengan Sikap Penggunaan sebagai Variabel Intervening
}

\author{
Dewi Kusuma Wardani ${ }^{1}$, Anita Primastiwi ${ }^{2}$ Hermalia $^{3}$ \\ ${ }^{1}$ Universitas Sarjanawiyata Tamansiswa \\ dewifeust@gmail.com, anitaprimas@ustjogja.ac.id,herm4lia@gmail.com
}

DOI: https://doi.org/10.24071/exero.v3i1.4240

\begin{abstract}
Abstrak
Penelitian ini bertujuan untuk memeriksa apakah kepentingan dirasakan dan dirasakan kenyamanan mempengaruhi bunga dalam membayar lahan dan pajak bangunan menggunakan Go-Pay melalui sikap sigunakan sebagai variable intervening. Metode penelitian ini menggunakan metode deskripsi kuantitatif dan data primer dengan menggunakan kuesioner. Penelitian ini menggunakan sampel dari 87 responden yang menggunakan Go-Pay dan merupakan pembayar pajak tanah dan membangun di daerah Sleman. Teknik sampling menggunakan convenience sampling. Data dikumpulkan dengan menggunakan kuesioner dalam Google Formulir dan kuesioner. Hasil penelitian ini menunjukkan bahwa penggunaan yang dianggap tidak berguna dan kemudahan yang dirasakan memiliki dampak positif pada sikap penggunaan dan sikap penggunaan memiliki dampak positif pada kepentingan dalam membuka lahan dan pajak bangunan dengan membayar langsung. Manfaat yang dirasakan dan kenyamanan memiliki efek positif pada bunga dalam membayar pajak tanah dan bangunan menggunakan Go-Pay melalui sikap penggunaan.
\end{abstract}

Kata kunci: dianggap berguna, kemudahan penggunaan, sikap penggunaan, pajak bangunan, pembayaran

\begin{abstract}
This study aims to examine whether the perceived usefulness and perceived convenience affect the interest in paying land and building tax using go-pay through the use attitude as an intervening variable. This research method uses quantitative description methods and primary data using a questionnaire. The study took a sample of 87 respondents who used gopay and were taxpayers of land and building in Sleman Regency. The sampling technique using convenience sampling technique. Data were collected by leaving a questionnaire in the google form and questionnaire. The results of this study indicate that the perceived usefulness and perceived ease of use have a positive effect on the attitude of use. Perceptions of usefulness, perceived ease of use and attitudes of use have a positive effect on interest in paying land and building taxes using go-pay. perceived usefulness and perceived convenience have a positive effect on interest in paying land and building tax using go-pay through usage attitudes.
\end{abstract}

Keywords: perceived usefulness, perceived ease of use, attitude of use, property tax, go-pay

\section{Pendahuluan}

Saat ini berbagai negara adanya penyebaran penyakit yaitu covid-19, dimana penyakit ini dapat menyebar melalui kontak langsung. Dimana dengan adanya covid19, masyarakat diharuskan untuk melakukan kegiatan dari rumah. Dengan ini upaya pemerintah agar masyarakat atau Wajib Pajak (WP) dapat melakukan pembayaran 
pajak secara online. Hal ini agar tidak ada terjadinya kerumunan di kantor pelayanan pajak sehingga dapat mengurangi penyebaran covid-19.

Sistem pembayaran secara online yang saat ini mulai berkembang dapat dimanfaatkan untuk melakukan pembayaran pajak secara online. Salah satu sistem pembayaran pajak secara online yaitu go-pay. Pajak yang dapat dibayarkan melalui go-pay adalah Pajak Bumi dan Bangunan (PBB). PBB merupakan pajak yang harus dibayarkan oleh WP karena memiliki hak atas tanah dan bangunan yang memiliki manfaat dari padanya. Tahun 2019 Badan Keuangan dan Aset Daerah (BKAD) Sleman mengungkapkan bahwa realisasi PBB di Kabupaten Sleman tidak mencapai ketetapan dan mengalami penurunan pendapatan dari tahun sebelumnya. Adapun realisasi pendapatan PBB Kabupaten Sleman tahun 2018 dan 2019 yaitu:

Tabel 1. Realisasi Pajak Bumi dan Bangunan Kabupaten Sleman

\begin{tabular}{ccccc}
\hline Tahun & $\begin{array}{c}\text { Jumlah } \\
\text { Ketetapan SPPT }\end{array}$ & $\begin{array}{c}\text { Ketetapan } \\
(\mathbf{R p})\end{array}$ & $\begin{array}{c}\text { Jumlah } \\
\text { Realisasi SPPT }\end{array}$ & $\begin{array}{c}\text { Realisasi } \\
(\mathbf{R p})\end{array}$ \\
\hline 2018 & 620.555 & $72 \mathrm{M}$ & 510.509 & $73,6 \mathrm{M}$ \\
2019 & 627.729 & $83 \mathrm{M}$ & 522.850 & $62,4 \mathrm{M}$ \\
\hline
\end{tabular}

Sumber: Tribunjogja.com (2020)

Dari Tabel di atas, dapat dilihat bahwa realisasi PBB Sleman pada tahun 2018 sebesar 73,6 Milyar dan mengalami penuruan pada tahun 2019 yaitu menjadi 62,4 Milyar. Pada tahun 2019 pendapatan PBB Sleman tidak mencapai dari jumlah ketetapan sebesar 83 miliar.

Faktor-faktor yang pengaruh minat membayar PBB menggunakan go-pay yaitu persepsi kemanfaatan dan persepsi kemudahan. Seandainya WP merasa bahwa menggunakan go-pay dapat memberi manfaat dan mudah digunakan maka WP akan berpikir positif serta tertarik untuk melakukan pembayaran PBB menggunakan gopay dan seandainya WP merasa bahwa pembayaran melalui go-pay tidak ada manfaat serta merasa sulit digunakan maka WP cenderung menghindari pajak yang harus dibayarkan (Prabawalingga \& Yadnyana, 2016).

Davis (1989) merupakan pengemuka Technology Acceptance Model (TAM) dan dispesialisasikan untuk memodelkan sistem pengguna terhadap suatu teknologi informasi. Di dalam TAM ini terdapat enam konstruk, yaitu persepsi kemanfaatan, persepsi kemudahan, variabel eksternal, sikap penggunaan, niat perilaku, dan 
penggunaan sebenarnya (Kurniawan et al., 2019). Beberapa penelitian menggunakan konstruk di dalam TAM untuk mengetahui tingkat keberterimaan suatu teknologi, khususnya teknologi baru, di dalam masyarakat.

Persepsi kemanfaatan didefinisikan Adam et.al (1992) yaitu sejauh mana kepercayaan setiap individu dalam penggunaan sistem dapat membuat prestasi kinerja meningkat (Permana et al., 2012). Bila bayar PBB secara manual, WP harus membayarnya di kantor BKAD dan sesuai peraturan WP harus ikut antrian yang membuat waktu WP terbuang sia-sia. Lebih efisien bila bayar PBB dilakukan dari rumah WP itu sendiri dengan membayar melalui go-pay, sebab WP bisa membayar kapan saja tanpa membuang-buang waktu dan tenaga. Semakin terus pengguna gopay merasa ada manfaatnya maka pengguna atau WP terdorong untuk memanfaatkan go-pay dalam membayar PBB. Sebab itu persepsi kemanfaatan mempunyai pengaruh positif pada minat bayar PBB menggunakan go-pay. Hal ini seiring dengan penelitian Laksana (2015), Aritonang \& Arisman (2017), Joan \& Sitinjak (2019), Pratama \& Suputra (2019), Monica \& Tama (2017) persepsi kemanfaatan memiliki pengaruh positif pada minat penggunaan sistem. Tetapi, bertentangan dengan penelitian Danurdoro \& Wulandari (2016) persepsi kemanfaatan tidak mempunyai pengaruh pada minat penggunaan internet banking.

Manfaat-manfaat yang dirasakan WP setelah membayar PBB melalui go-pay maka WP berpikir positif terhadap go-pay untuk bayar PBB. Sebab itu, persepsi kemanfaatan mempunyai pengaruh positif pada sikap pernggunaan. Hal ini seiring dengan penelitian Umamah \& Pribadi (2006), Rusfianto et al. (2016), dan Salsabila (2016) persepsi kemanfaatan mempunyai pengaruh positif pada sikap penggunaan. Tetapi, bertentangan dengan penelitian Aidar (2018) persepsi kemanfaatan tidak mempunyai pengaruh positif pada sikap penggunaan layanan mobile banking.

Persepsi kemudahan didefinisi Davis (1989) yaitu sejauh mana kepercayaan seseorang dalam penggunaan sistem mudah di mengerti (Permana et al., 2012). Bila pengguna go-pay, merasa go-pay mudah di pahami, di mengerti, dan di operasi, maka WP terdorong untuk sering bayar PBB melalui go-pay. Sebab itu, persepsi kemudahan mempunyai pengaruh positif pada minat bayar PBB menggunakan gopay. Hal ini seiring dengan penelitian Laksana (2015), Aritonang \& Arisman (2017), Joan \& Sitinjak (2019), Pratama \& Suputra (2019) persepsi kemudahan mempunyai 
pengaruh positif pada minat penggunaan sistem. Tetapi, bertentangan dengan penelitian Monica \& Tama (2017) dan Wong et al. (2013) persepsi kemudahan tidak mempunyai pengaruh pada minat menggunakan sistem.

Kemudahan yang telah dirasakan WP bertransaksi melalui go-pay untuk bayar PBB seperti mudah di pahami, di mengerti, dan di operasi maka WP akan memiliki perasaan suka serta bertindak secara berulang untuk bayar PBB melalui gopay. Penelitian ini seiring dengan penelitian Rusfianto et al. (2016), Umamah \& Pribadi (2006) dan Salsabila (2016) persepsi kemudahan mempunyai pengaruh positif pada sikap penggunaan. Tetapi, bertentangan dengan penelitian Peranginangin et al. (2016), Wong et al. (2013) Perceived ease of use tidak mempunyai pengaruh positif pada attitude toward using.

Sikap setiap orang terdiri dari unsur kognitif dan afektif yang bersangkutan dengan sebuah perilaku. Bila pengguna atau WP suka bayar PBB melalui go-pay sebab merasa mudah dipergunakan dan mempunyai manfaat maka WP tertarik untuk bayar PBB melalui go-pay. Sebab itu, sikap penggunaan mempunnyai pengaruh positif pada minat bayar PBB melalui go-pay. Hal ini seiring pada penelitian Rithmaya (2016) dan Bangkara \& Mimba (2016) sikap penggunaan mempunyai pengaruh positif pada minat penggunaan. Tetapi, bertentangan dengan penelitian Ningtyas \& Nazar (2016) Sikap penggunaan tidak berpengaruh positif pada minat penggunaan ERP.

Apabila seseorang membayar PBB menggunakan go-pay merasakan manfaat bagi dirinya untuk masa depan maka akan menimbulkan sikap atau tindakan positif, kemudian ketika seseorang sudah memiliki sikap positif maka akan timbul kemauan untuk membayar PBB menggunakan go-pay. Sebab itu, persepsi kemanfaatan mempunyai pengaruh positif pada minat bayar membayar PBB menggunakan go-pay melalui sikap penggunaan. Hal ini seiring pada penelitian Bangkara \& Mimba (2016) yang mengutaran Perceived usefulness mempunyai pengaruh positif pada minat (intention) melalui attitude toward using. Tetapi, bertentangan dengan penelitian Danurdoro \& Wulandari (2016) persepsi kemanfaatan tidak mempunyai pengaruh pada minat penggunaan internet banking. Ningtyas \& Nazar (2016) Sikap penggunaan tidak berpengaruh positif pada minat penggunaan ERP. 
Apabila WP membayar pajak melalui go-pay merasa mudah maka WP bersikap positif atau memberi tindakan positif, kemudian ketika seseorang sudah memiliki perasaaan positif maka akan timbul kemauan untuk bayar PBB melalui gopay. Hal ini seiring dengan penelitian Bangkara \& Mimba (2016) mengungkapkan Perceived ease of use mempunyai pengaruh positif pada minat (intention) melalui attitude toward using. Tetapi, bertentangan dengan penelitian Monica \& Tama (2017) dan Wong et al. (2013) persepsi kemudahan tidak mempunyai pengaruh pada minat penggunaan sistem. Ningtyas \& Nazar (2016) Sikap penggunaan tidak berpengaruh positif pada minat penggunaan ERP.

Dari paparan diatas, maka periset terdorong untuk melakukan penelitian tentang minat bayar pajak dengan adanya pembayaran PBB melalui go-pay. pembeda penelitian ini sama penelitian lainnya yaitu periset menambahkan pembayaran PBB melalui go-pay pada variabel dependen, dimana sistem ini belum ada diteliti oleh periset lainnya karena sistem ini masih sangat baru dalam membayar PBB. Periset memakai 4 (empat) variabel dari teori TAM yaitu persepsi kemanfaatan dan persepsi kemudahan sebagai variabel independen, minat membayar PBB menggunakan gopay sebagai variabel dependen dan sikap penggunaan sebagai variabel intervening.

\section{Kajian Literatur}

\section{Technology Acceptance Model (TAM)}

TAM adalah aplikasi yang dikembangkan dari Theory of Reasoned Action (TRA) serta di modernkan pada penerimaan pemakai terhadap sistem informasi. Model TAM ini dilandaskan dari sikap, kepercayaan, hubungan perilaku pengguna dan intensitas (Prabawalingga \& Yadnyana, 2016). Davis (1989) mengutarakan TAM yaitu persepsi kemanfaatan, persepsi kemudahan pengguna, sikap, niat perilaku dan penggunaan sebenarnya.

\section{Pajak Bumi dan bangunan}

Berdasarkan pada lembaga pemungutannya, pajak terbagi jadi dua, ialah pajak pusat dan daerah. Pajak yang diatur pemerintah daerah yaitu disebut Pajak Daerah. Pajak daerah adalah pajak yang dibayarkan masyarakat untuk digunakan sebagai pembiayaan pembangunan daerah (Ismail, 2018). Pajak daerah adalah biaya yang wajib dibayarkan oleh WP dan dianggap sebagai terutang yang memiliki sifat 
pemaksaan tanpa menerima imbalan secara langsung dan akan dipakai untuk pembangunan daerah (Wulandari \& Iryanie, 2018). PBB termasuk sumber pemasukan negara yang cukup potensial yang berasal dari pajak daerah. PBB adalah iuran yang ditanggung badan maupun orang pribadi yang mempunyai hak-hak individu atas bumi dan hak-hak individu atas bangunan serta mendapatkan manfaat dari padanya.

\section{Go-Pay}

Go-Pay merupakan uang elektronik untuk melakukan pembayaran dan berbagai macam transaksi keuangan yang dapat digunakan melalui aplikasi Gojek (gojek.com). Go-Pay adalah alat yang digunakan untuk pembayaran PBB di Kabupaten Sleman. Go-Pay ini telah disahkan sebagai salah satu sarana untuk membayarkan PBB sejak 11 September 2019. Pengesehan ini ditandai dengan adanya penenandataganan Memorandum of Understanding (MoU) antara Bank BPD DIY dengan PT Dompet Anak Bangsa sebagai perusahaan yang mengelola Go-Pay tentang kesepakatan mengenai layanan pembayaran tagihan (Multibiller) secara online (jogja.tribunnews.com). Pembayaran PBB dapat dilakukan melalui fitur GoBills yang tersedia di aplikasi Gojek.

\section{Minat Membayar Pajak}

Minat membayar PBB penggunaan Go-Pay adalah niat perilaku WP untuk terus menerus menggunakan Go-Pay dalan pembayaran PBB. Terdapat 3 (tiga) indikator yang dipakai untuk pengukuran variabel minat membayar PBB menggunakan Go-Pay yaitu motif sosial yang membangkitkan minat, adanya dorongan dalam diri individu, dan adanya faktor emosional. Ketiga inidikator ini dinyatakan di dalam 3 (tiga) pernyataan di dalam kuesioner.

\section{Persepsi Kemanfaatan}

Persepsi kemanfaatan didefinisi sebagai sejauh mana kepercayaan setiap individu dalam penggunaan suatu sistem dapat membuat prestasi pekerjaannya meningkat (Permana et al., 2012). Menurut Davis (1989) Persepsi manfaat adalah tingkatan sejauh mana kepercayaan pada setiap diri individu ketika akan menggunakan suatu sistem informasi dapat memberikan peningkatan kinerja mereka (Laksana, 2015). 


\section{Persepsi Kemudahan}

Persepsi kemudahan didefinisi Davis (1989) yaitu sejauh mana kepercayaan seseorang dalam penggunaan sistem mudah dipahami (Permana et al., 2012). Jogiyanto (2007) mengutarakan persepsi kemudahan adalah sebagai tingkatan kepercayaan pada setiap diri individu bahwa penggunaan sistem dapat dibebaskan dari suatu usaha (Pratama \& Suputra, 2019). Terdapat tiga indikator yaitu mudah dipahami, mudah dioperasikan dan efisien.

\section{Sikap Penggunaan}

Teori TAM mengutarakan bahwa sikap penggunaan adalah sikap seorang individu dalam menggunakan suatu sistem yang terlihat apakah seseorang menerima atau menolak serta memandang positif atau negatif dari sistem yang telah dipergunakannya (Rithmaya, 2016). Sikap penggunaan dapat terpengaruh dari persepsi kemanfaatan dan persepsi kemudahan, artinya manfaat dan kemudahan yang dirasa setiap individu untuk mamakai suatu sistem maka setiap individu tersebut memberi tanggapan positif dan menerima sistem tersebut.

\section{Persepsi Kemanfaatan pada Sikap Penggunaan}

Persepsi kemanfaatan didefinisi sebagai sejauh mana kepercayaan setiap individu dalam penggunaan suatu sistem dapat membuat prestasi pekerjaannya meningkat (Permana et al., 2012). Teori TAM mengutarakan bahwa sikap penggunaan adalah sikap seorang individu dalam menggunakan suatu sistem yang terlihat apakah seseorang menerima atau menolak serta memandang positif atau negatif dari sistem yang telah dipergunakannya (Rithmaya, 2016). Bila WP merasa menggunakan go-pay mempunyai manfaat sehingga mengurangi pekerjaannya maka WP akan memiliki pandangan positif dan go-pay diterima sebagai transaksi bayar PBB.

Penelitian Salsabila (2016) mengutaran bahwa persepsi kemanfaatan mempunyai pengaruh positif pada sikap penggunaan Sistem Informasi Akademik Mahasiswa (SIAM), hal ini berasumsi bahwa semakin tinggi manfaat yang ddirasakan dari Sistem Informasi Akademik Mahasiswa (SIAM), maka semakin positif pula sikapnya untuk menggunakan. Berdasarkan paparan di atas hipotesis yang diujikan adalah:

H1: Persepsi kemanfaatan berpengaruh positif pada sikap penggunaan 


\section{Persepsi Kemudahan pada Sikap Penggunaan}

Persepsi kemudahan didefinisi Davis (1989) yaitu sejauh mana kepercayaan seseorang dalam penggunaan sistem mudah dipahami (Permana et al., 2012). Bila WP memiliki pandangan bahwa bayar PBB melalui go-pay mudah untuk dipergunakan tanpa ada kendala maka WP akan suka dan terus menggunakan. Penelitian Rusfianto et al. (2016) mengutaran bahwa kemudahan penggunaan mempunyai pengaruh positif pada sikap penggunaan. Berdasarkan paparan di atas hipotesis yang diujikan adalah:

H2: Persepsi kemudahan berpengaruh positif pada sikap penggunaan

\section{Persepsi Kemanfaatan pada Minat Membayar Pajak Bumi dan Bangunan Menggunakan Go-Pay}

Menurut Davis (1989) Persepsi manfaat adalah tingkatan sejauh mana kepercayaan pada setiap diri individu ketika akan menggunakan suatu sistem informasi dapat memberikan peningkatan kinerja mereka (Laksana, 2015). Dari definisi, diketahui bahwa persepsi manfaat yang dirasakan WP dapat meningkatkan minat WP membayar PBB melalui go-pay.

Minat membayar pajak adalah sesuatu dimana seseorang sanggup untuk mengeluarkan, mengor-bankan atau menukarkan uang untuk menerima barang atau jasa (Widarto et al., 2013) . Tetapi, masih ada WP yang tidak tertarik untuk bayar pajak, salah satunya Pajak Bumi dan Bangunan. Disebabkan WP enggan untuk datang ke kantor BKAD sebab harus mengikuti antrian yang membuat WP menunggu lama. Denga hal ini, WP bisa memanfaatkan handphone untuk bertransaksi melalui go-pay dalam bayar PBB karena WP bisa membayar dari rumah nya sendiri. Sehingga dengan adanya go-pay ini dapat meningkatkan ketertarikan WP dalam membayar pajaknya.

Penelitian Monica \& Tama (2017), Salimi et al. (2020), Wong et al. (2013) menunjukkan bahwa persepsi manfaat mempunyai pengaruh positif pada minat menggunakan sistem, artinya semakin meningkat kegunaan yang dirasakan maka semakin meningkat juga minat untuk menggunakannya. Berdasarkan paparan di atas hipotesis yang diujikan adalah:

H3: Persepsi kemanfaatan berpengaruh positif pada minat membayar PBB menggunakan Go-Pay 


\section{Persepsi Kemudahan pada Minat Membayar Pajak Bumi dan Bangunan Menggunakan Go-Pay}

Persepsi kemudahan yaitu tingkatan kepercayaan pada setiap diri individu bahwa penggunaan suatu sistem dan teknologi dapat dibebaskan dari usaha (Pratama \& Suputra, 2019). Dari definisi, diketahui go-pay yang digunakan untuk transaksi membayar PBB tidak dibutuhkan waktu yang lama serta bisa dibayarkan kapan saja. Bila WP berpikir positif pada pembayaran PBB melalui go-pay sebab mudah tanpa ada kendala maka WP senang serta tertarik untuk bayar PBB melalui go-pay.

Penelitian Joan \& Sitinjak (2019) mengungkapkan persepsi kemudahan mempunyai pengaruh positif pada minat penggunaan layanan go-pay. Dari paparan di atas hipotesis yang diujikan adalah:

$\mathbf{H}_{4}$ : Persepsi kemudahan berpengaruh positif pada minat membayar PBB menggunakan Go-Pay

\section{Sikap Penggunaan pada Minat Membayar Pajak Bumi dan Bangunan Menggunakan Go-Pay}

Teori TAM mengungkapkan sikap penggunaan adalah sikap seorang individu dalam menggunakan suatu sistem yang terlihat apakah seseorang menerima atau menolak serta memandang positif atau negatif dari sistem yang telah dipergunakannya. Minat membayar pajak dapat terpengaruh dari persepsi sesorang mempunyai manfaat dan kemudahan, di mana sikap penggunaan sebagai jembatan hubungan persepsi kemanfaatan dan kemudahan pada minat membayar PBB menggunakan go-pay.

Penelitian Bangkara \& Mimba (2016), Putra et al. (2019) mengutarakan bahwa sikap penggunaan mempunyai pengaruh positif pada minat penggunaan. Dari paparan di atas hipotesis yang diujikan adalah:

H5: Sikap penggunaan berpengaruh positif pada minat membayar PBB menggunakan Go-Pay

\section{Persepsi Kemanfaatan pada Minat Membayar Pajak Bumi dan Bangunan Menggunakan Go-Pay Melalui Sikap Penggunaan}

Persepsi kemanfaatan merupakan pandangan setiap pengguna terhadap seberapa besar suatu sistem dapat meningkatkan kinerjanya (Joan \& Sitinjak, 2019). Apabila seseorang membayar pajak akan berdampak positif atau memiliki manfaat bagi dirinya untuk masa depan maka akan menimbulkan sikap atau tindakan positif 
sehingga persepsi kemanfaatan berpengaruh positif terhadap sikap. Semakin tinggi persepsi manfaat seseorang maka semakin tinggi juga sikap untuk melakukan sesuatu hal itu, kemudian ketika seseorang sudah memiliki perasaaan positif maka akan timbul kemauan untuk membayar PBB menggunakan go-pay, di mana kemauan itu akan merujuk pada minat dan keinginan seseorang untuk membayar PBB sehingga persepsi manfaat mempunyai pengaruh positif pada minat membayar PBB menggunakan go-pay melalui sikap penggunaan.

Penelitian Bangkara \& Mimba (2016) mengutarakan Perceived usefulness mempunyai pengaruh positif pada intention melalui attitude toward using. Dari paparan di atas hipotesis yang diujikan adalah:

H6: Persepsi kemanfaatan berpengaruh positif pada minat membayar PBB menggunakan Go-Pay melalui sikap penggunaan

\section{Persepsi Kemudahan pada Minat Membayar Pajak Bumi dan Bangunan Menggunakan Go-Pay Melalui Sikap Penggunaan}

Persepsi kemudahan merupakan tingkat bayangan pengguna terhadap usaha yang harus dikeluarkan dalam penggunaan suatu sistem (Joan \& Sitinjak, 2019). Apabila seseorang membayar pajak menggunakan go-pay akan berdampak positif atau memiliki kemudahan dalam melakukan pembayarannya maka akan menimbulkan sikap positif atau tindakan positif sehingga persepsi kemudahan mempunyai pengaruh positif pada sikap. Semakin tinggi kemudahan yang dirasa maka semakin tinggi sikap untuk melakukan sesuatu hal, kemudian ketika seseorang sudah memiliki perasaaan positif maka akan timbul kemauan untuk membayar PBB menggunakan go-pay, di mana kemauan itu akan merujuk pada minat dan keinginan seseorang untuk membayar PBB sehingga persepsi kemudahan mempunyai pengaruh positif pada minat membayar PBB menggunakan go-Pay melalui sikap penggunaan.

Penelitian Bangkara \& Mimba (2016) mengutarakan Perceived ease of use mempunyai pengaruh positif pada intention melalui attitude toward using. Dari paparan di atas yang diujikan adalah:

H7: Persepsi kemudahan berpengaruh positif pada minat membayar PBB menggunakan Go-Pay melalui sikap penggunaan 


\section{Kerangka Pikir}

Kerangka pikir pada penelitian ini adalah sebagai berikut:

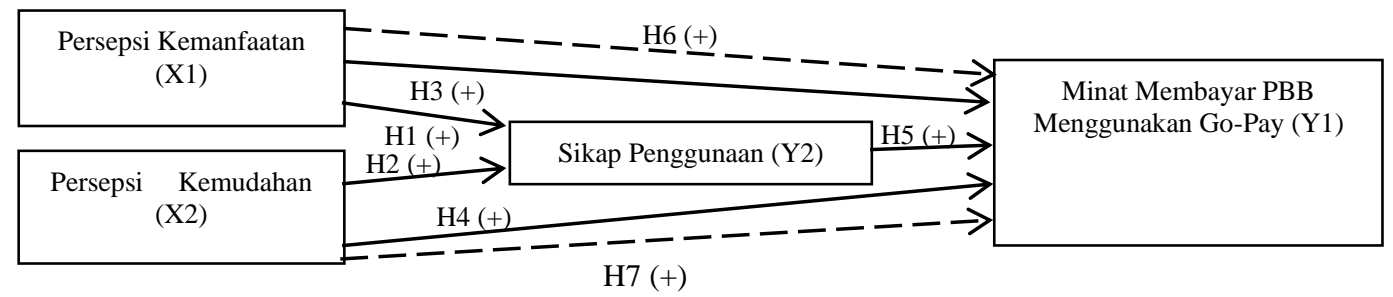

\section{Gambar 1. Kerangka Pikir}

\section{Metode Penelitian}

Populasi yang dipakai dalam penelitian ini adalah semua WP yang dikenakan PBB di Kabupaten Sleman, DIY. Jumlah sampel sebanyak 87 responden yang diambil menggunakan teknik covenience sampling. Data yang dipergunakan pada penelitian ini yaitu data primer. Data primer ini akan didapat dari jawaban responden. Teknik yang dipakai untuk mengambil data yaitu dengan menyebar kuisioner berupa angket dan google form pada pengguna go-pay dan WP yang telah dikenakan PBB di Kabupaten Sleman, DIY.

\section{Hasil Dan Pembahasan}

\section{Uji Kecocokan Model Pengukuran (Outer Model)}

Hail uji validitas yang diolah sebanyak 87 kuisioner adalah sebagai berikut:

Tabel 2.Hasil Uji Validitas

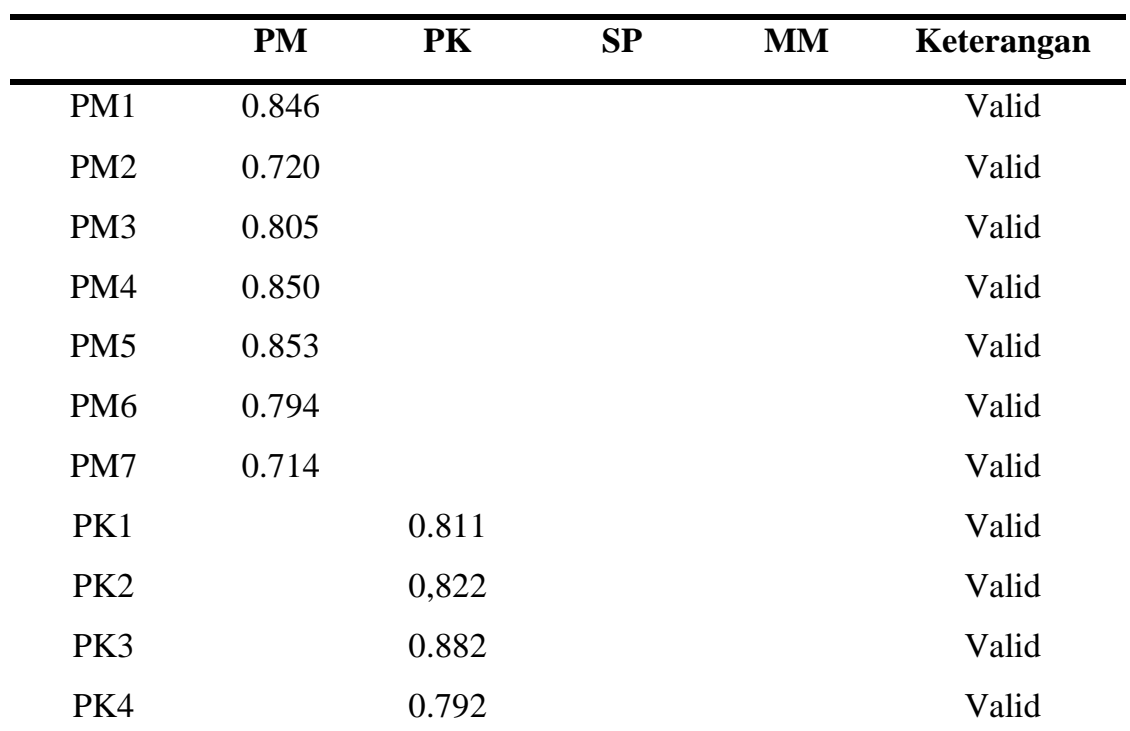




\begin{tabular}{ccccc} 
PK5 & 0.708 & & & Valid \\
PK6 & 0.888 & & & Valid \\
PK7 & 0.881 & & & Valid \\
SP1 & & 0.873 & & Valid \\
SP2 & & 0.931 & & Valid \\
SP3 & 0.905 & & Valid \\
MM1 & & 0.901 & Valid \\
MM2 & & 0.922 & Valid \\
MM3 & & 0.884 & Valid \\
\hline
\end{tabular}

Sumber: Data primer diolah 2020

Tabel diatas mengungkapkan bahwa semua butir pernyataan dikatakan valid karena terbukti dari nilai loading factor diatas 0.70. Uji reliabilitas diolah dengan program SmartPLS versi 3.0. Berikut adalah hasil uji reliabilitas:

Tabel 3. Hasil Uji Reliabilitas

\begin{tabular}{cccc}
\hline & Composite Reliability & Cronbach's Alpha & Keterangan \\
\hline PM & 0.925 & 0.905 & Reliabel \\
PK & 0.938 & 0.938 & Reliabel \\
SP & 0.930 & 0.887 & Reliabel \\
MM & 0.930 & 0.886 & Reliabel \\
\hline
\end{tabular}

Sumber: Data primer diolah 2020

Dari tabel 3 disimpulkan bahwa semua variabel dikatakan reliabel sebab nilai composite reliability dan nilai cronbach's alpha diatas 0.50 .

\section{Uji Kecocokan Model Struktural (Inner Model)}

Berikut ini adalah hasil uji kecocokan model struktural (inner model):

Tabel 4. Nilai R-Square

\begin{tabular}{cc}
\hline Variabel & R-Square \\
\hline MM & 0.759 \\
SP & 0.752 \\
\hline
\end{tabular}

Sumber: Data primer diolah 2020

Nilai $R$-Square untuk variabel MM memiliki nilai yaitu 0,759 yang berarti termasuk dalam kategori korelasi yang kuat dan nilai $R$-Square pada variabel SP yaitu 0,752 , artinya termasuk kategori korelasi yang kuat. 
Tabel 5. Nilai Path Coefficients

\begin{tabular}{cccccc}
\hline & $\begin{array}{c}\text { Original } \\
\text { Sampel }(\mathbf{O})\end{array}$ & $\begin{array}{c}\text { Sampel } \\
\text { Mean }(\mathbf{M})\end{array}$ & $\begin{array}{c}\text { Standard Error } \\
(\text { STERR })\end{array}$ & $\begin{array}{c}\text { T-Statistics } \\
(\text { O/STERR) }\end{array}$ & P-Values \\
\hline PM => SP & 0.463 & 0.446 & 0.122 & 3.789 & 0.000 \\
PM => MM & 0.216 & 0.224 & 0.121 & 1.992 & 0.047 \\
PK => SP & 0.429 & 0.442 & 0.116 & 3.700 & 0.000 \\
PK => MM & 0.355 & 0.346 & 0.144 & 2.464 & 0.014 \\
SP => MM & 0.344 & 0.377 & 0.107 & 3.209 & 0.001 \\
PM => SP => MM & 0.159 & 0.152 & 0.068 & 2.328 & 0.020 \\
PK => SP => MM & 0.148 & 0.147 & 0.059 & 2.500 & 0.013 \\
\hline Sum
\end{tabular}

Sumber: Data primer diolah 2020

\section{Pembahasan}

Hipotesis 1 pada penelitian ini yaitu persepsi kemanfaatan mempunyai pengaruh pada sikap penggunaan. Hasil uji hipotesis yang telah dilakukan menghasilkan persepsi kemanfaatan mempunyai pengaruh positif pada sikap penggunaan. Hal ini terbukti dari nilai T-statistik 3,789 dan memiliki nilai original sample estimate sebesar 0,463. Hasil diperkuat dengan jawaban responden yang mayoritas mengisi sangat setuju dengan persentase $52,9 \%$ pada pernyataan responden yang merasa senang menggunakan go-pay dalam pembayaran PBB karena mempercepat pekerjaan sehingga $\mathrm{H}_{1}$ terdukung.

Hasil penelitian ini sejalan dengan Salsabila (2016) menganalisis pengaruh persepsi kemanfaatan terhadap sikap penggunaan dalam penggunaan Sistem Informasi Akademik Mahasiswa (SIAM). Penelitian ini seiring dengan tujuan TAM yang menunjukkan pengaruh persepsi kemanfaatan yang positif dan signifikan pada sikap penggunaan. Hasil penelitian tersebut menunjukkan persepsi kemanfaatan mempunyai pangaruh yang positif dan signifikan pada sikap penggunaan. Hal ini artinya, semakin tinggi manfaat yang dirasa, maka akan tinggi juga sikap penggunaannya.

Hipotesis 2 pada penelitian ini yaitu persepsi kemudahan bmempunyai pengaruh pada sikap penggunaan. Hasil uji ini hipotesis yang telah dilakukan menghasilkan bahwa persepsi kemudahan mempunyai pengaruh positif pada sikap penggunaan. Hal ini dibuktikan dari nilai T-statistik yaitu 3,700 (>1,96) dan nilai 
original sample estimate yaitu 0,429. Hasil ini diperkuat dengan jawaban responden yang mayoritas mengisi sangat setuju dengan persentase $48,3 \%$ pada pernyataan responden yang menyukai go-pay karena membantu proses pembayaran PBB sehingga $\mathrm{H}_{2}$ terdukung.

Hasil penelitian ini seiring dengan penelitian Rusfianto et al. (2016), Putra et al. (2019) dan sejalan dengan tujuan TAM mengutaran pengaruh persepsi kemudahan yang positif dan signifikan pada sikap penggunaan. Hal tersebut diartikan, semakin tinggi kemudahan yang dirasa WP maka semakin tinggi tingkat untuk menyukai penggunaan go-pay dalam pembayaran PBB.

Hipotesis 3 pada penelitian ini yaitu persepsi kemanfaatan berpengaruh pada minat membayar PBB menggunakan go-pay. Hasil uji ini hipotesis yang telah dilakukan menghasilkan bahwa persepsi kemanfaatan mempunyai pengaruh positif pada minat membayar PBB menggunakan go-pay. Hal tersebut terbukti dari nilai Tstatistik yaitu 1,992 (>1,96) dan nilai original sample estimate yaitu 0,216. Hasil ini diperkuat dari jawaban responden yang mayoritas mengisi sangat setuju dengan persentase $58,6 \%$ pada pernyataan responden memiliki keinginan untuk membayar PBB menggunakan go-pay sehingga $\mathrm{H}_{3}$ mendukung.

Hasil penelitian ini seiring pada penelitian yang dilakukan Joan \& Sitinjak (2019), Monica \& Tama (2017), Salimi et al. (2020) dan sejalan dengan tujuan TAM mengungkapkan pengaruh persepsi kemanfaatan yang positif pada minat penggunaan. Hal tersebut diartikan, semakin tinggi manfaat yang dirasak wajib pajak maka semakin tinggi minat untuk membayar PBB menggunakan go-pay.

Hipotesis 4 pada penelitian ini yaitu persepsi kemudahan berpengaruh terhadap minat membayar PBB menggunakan go-pay. Hasil uji hipotesis yang telah dilakukan menghasilkan bahwa persepsi kemudahan mempunyai pengaruh positif pada minat membayar PBB menggunakan go-pay. Hal tersebut terbukti dari nilai Tstatistik yaitu 2,464 $(>1,96)$ dan nilai original sample estimate yaitu 0.355. Hasil penelitian ini diperkuat dengan jawaban responden yang mayoritas mengisi sangat setuju dengan persentase $63,2 \%$ pada pernyataan responden yang tertarik membayar PBB menggunakan go-pay sehingga $\mathrm{H}_{4}$ mendukung.

Hasil penelitian ini seiring pada penelitian Rusfianto et al. (2016), Umamah \& Pribadi (2006), Salsabila (2016) dan sejalan dengan tujuan TAM yang menyatakan 
pengaruh persepsi kemudahan yang positif pada minat penggunaan. Hal ini artinya semakin tinggi tingkat kemudahan yang dirasak WP maka semakin tinggi minat untuk membayar PBB menggunakan go-pay.

Hipotesis 5 pada penelitian ini yaitu sikap penggunaan berpengaruh pada minat membayar PBB menggunakan go-pay. Hasil uji hipotesis yang telah dilakukan menghasilkan bahwa sikap penggunaan mempunyai pengaruh positif pada minat membayar PBB menggunakan go-pay. Hal ini terbukti dari nilai T-statistik yaitu $3,209(>1,96)$ dan nilai original estimate yaitu 0,344 . Hasil penelitian ini diperkuat dengan jawaban responden yang mayoritas mengisi sangat setuju dengan persentase $62,1 \%$ pada pernyataan responden mempunyai keyakinan bahwa membayar PBB menggunakan go-pay adalah pilihan terbaik sehingga $\mathrm{H}_{5}$ terdukung.

Hasil ini menyatakan bahwa WP mempunyai sikap pada layanan go-pay dalam pembayaran PBB maka mereka akan merubah sikapnya mengikuti perkembangan teknologi. Hal ini seiring dengan penelitian Rithmaya (2016), Bangkara \& Mimba (2016) dan sejalan dengan tujuan TAM yang menyatakan bahwa sikap penggunaan mempunyai pengaruh positif pada minat penggunaan. Hal ini mengungkapkan bahwa wajib pajak mempunyai sikap positif, dengan adanya go-pay maka WP akan merubah kebiasaan mereka sesuai dengan perkembangan zaman yaitu adanya sistem pembayaran go-pay.

Hipotesis 6 pada penelitian ini yaitu persepsi kemanfaatan berpengaruh pada minat membayar PBB menggunakan go-pay melalui sikap penggunaan. Hasil uji hipotesis yang telah dilakukan menghasilkan bahwa persepsi kemanfaatan mempunyai pengaruh positif pada minat membayar PBB menggunakan go-pay melalui sikap penggunaan. Hal tersebut dibuktikan pada nilai T-statistik yaitu 2,328 $(>1,96)$ dan nilai original estimate yaitu 0,159 sehingga $\mathrm{H}_{6}$ terdukung.

Hasil penelitian ini mengungkapkan manfaat yang dirasakan dapat membuat wajib pajak merasa senang dan menyukai layanan go-pay sehingga wajib pajak tertarik untuk bayar PBB melalui go-pay. Hasil ini seiring dengan tujuan TAM yang mengukur persepsi kemanfaatan berpengaruh positif terdahap minat penggunaan melalui sikap penggunaan. Hal ini menunjukkan bahwa persepsi kemanfaatan yang dirasakan dapat menimbulkan sikap senang dan menyukai sehingga membuat ketertarikan membayar PBB menggunakan go-pay. 
Hipotesis 7 pada penelitian ini yaitu persepsi kemudahan berpengaruh pada minat membayar PBB menggunakan go-pay melalui sikap penggunaan. Hasil uji hipotesis ini menghasilkan bahwa persepsi kemudahan mempunyai pengaruh positif pada minat membayar PBB menggunakan go-pay melalui sikap penggunaan. Hal tersebut dibuktikan dari nilai T-statistik yaitu 2,500 (>1,96) dan nilai original estimate yaitu 0,148 sehingga $\mathrm{H}_{7}$ terdukung.

Hasil penelitian ini mengungkapkan kemudahan layanan go-pay yang dirasakan dapat membuat WP merasa senang dan menyukai layanan go-pay sehingga wajib pajak tertarik untuk bayar PBB melalui go-pay. Hasil penelitian ini seiring dengan tujuan TAM yang mengukur persepsi kemudahan mempunyai pengaruh positif pada minat penggunaan melalui sikap penggunaan. Hal ini menunjukkan persepsi kemudahan yang dirasakan dapat menimbulkan sikap senang dan menyukai sehigga membuat ketertarikan membayar PBB menggunakan go-pay.

\section{Kesimpulan, Implikasi, Saran dan Keterbatasan}

Penelitian ini dilakukan pada 87 responden yaitu pengguna go-pay dan WP PBB di Kabupaten Sleman. Dari hasil penelitian dapat disimpulkan persepsi kemanfaatan dan persepsi kemudahan mempunyai pengaruh positif pada sikap penggunaan. Persepsi kemanfaatan dan persepsi kemudahan mempunyai pengaruh positif pada minat membayar PBB menggunakan go-pay. Sikap penggunaan mempunyai pengaruh positif pada minat membayar PBB menggunakan go-pay. Persepsi kemanfaatan mempunyai pengaruh positif pada minat membayar PBB menggunakan go-pay melalui sikap penggunaan. Persepsi kemudahan mempunyai pengaruh positif pada minat membayar PBB menggunakan go-pay melalui sikap penggunaan.

Penelitian memiliki keterbatasan yaitu: Penelitian ini cuma mencakup dua variabel independen yaitu, persepsi kemanfaatan dan persepsi kemudahan dengan satu variabel intervening yaitu sikap penggunaan untuk mengetahui pengaruh terhadap minat membayar PBB menggunakan go-pay dan penelitian ini hanya diambil dari satu sumber data penelitian yaitu kuisioner. Oleh karena itu, data yang didapat hanya menggambarkan pendapat responden dari kuisioner, akan tetapi kuisioner juga memiliki kekurangan dimana jawaban responden terkadang tidak mengatakan keadaan yang sebenarnya. Hal ini dapat terjadi karena responden tidak 
objektif atau tidak dapat memahami pernyataan yang tertera dalan kuisioner dengan baik.

Saran untuk Badan Keuangan Aset Daerah (BKAD) Sleman diharapkan dapat membuat sosialisasi tentang manfaat dan tata cara penggunaan layanan go-pay agar wajib pajak bisa memahaminya. Saran untuk Wajib Pajak diharapkan dapat mengikuti kegiatan sosialisasi pembayaran PBB secara online salah satunya menggunakan go-pay agar wajib pajak bisa memahami cara penggunaanya. Saran untuk peneliti selanjutnya, peneliti ini masih terbatas pada variabel independen dan variabel intervening yang digunakan, oleh sebab itu periset selanjutnya diharapkan dapat menambahkan variabel baru dalam penelitian ini, seperti perilaku dan lingkungan yang perlu diteliti.

\section{Referensi}

Aidar, A. ayu nur. (2018). Pengeruh Persepsi Manfaat, Kemudahan Penggunaan, Dan Kepercayaan Terhadap Sikap Penggunaan Layanan Mobile Banking (Studi Pada Dosen Iain Surakarta Pengguna Layanan Mobile Banking. 2. https://doi.org/10.20961/ge.v4i1.19180

Andrian, A., Kertahadi, \& Susilo, H. (2013). Analisis Pengaruh Persepsi Kegunaan, Persepsi Kemudahan, Dan Sikap Penggunaan Terhadap Minat Perilaku Penggunaan Billing System. Journal of Chemical Information and Modeling, 53(9), 1689-1699. https://doi.org/10.1017/CBO9781107415324.004

Aritonang, Y. A. L., \& Arisman, A. (2017). Pengaruh persepsi kemudahan dan persepsi manfaat terhadap minat menggunakan E-Money (STUDI KASUS PADA PENGGUNA GO-PAY). Jurnal Akuntansi STIE Multi Data Palembang, $x, 1-17$.

Bangkara, R., \& Mimba, N. (2016). Pengaruh Perceived Usefulness Dan Perceived Ease of Use Pada Minat Penggunaan Internet Banking Dengan Attitude Toward Using Sebagai Variabel Intervening. E-Jurnal Akuntansi, 16(3), 2408-2434.

Danurdoro, K., \& Wulandari, D. (2016). The Impact of Perceived Usefulness, Perceived Ease of Use, Subjective Norm, and Experience Toward Student's Intention to Use Internet Banking. Jurnal Ekonomi Dan Ekonomi Studi Pembangunan, 8(1), 17-22. https://doi.org/10.17977/um002v8i12016p017

Ismail, T. (2018). Potret Pajak Daerah Di Indonesia. Kencana.

Joan, L., \& Sitinjak, T. (2019). Pengaruh Persepsi Kebermanfaatan Dan Persepsi Kemudahan Penggunaan Terhadap Minat Penggunaan Layanan Pembayaran Digital Go-Pay. Jurnal Manajemen, 8(2), 27-39.

Kurniawan, T. A., Wardani, D. K., \& Widhayati, L. (2019). Pengaruh Keberterimaan Layanan Peer to Peer Lending Kepada Umkm Sebagai Pengguna Dengan Menggunakan Metode Technology Acceptance Model (TAM). Jurnal Sosial Ekonomi Dan Humaniora (JSEH), 5, 151-160.

Laksana, G. B. (2015). Pengaruh Persepsi Kemanfaatan, Persepsi Kemudahan Penggunaan, Persepsi Resiko Dan Persepsi Kesesuaian Terhadap Minat Menggunakan Mobile Banking (Studi Pada Nasabah Bank Rakyat Indonesia 
(Bri) Kantor Cabang Rembang, Jawa Tengah). Jurnal Administrasi Bisnis, 26(2), 1-8.

Monica, N., \& Tama, annafi indra. (2017). Pengaruh Persepsi Manfaat, Persepsi Kemudahan, Persepsi Kenyamanan, Norma Subjektif dan Kepercayaan Terhadap Minat Menggunakan Elektronik Commerce. JRAK Vol.8 No.1 Februari 2017, 8(April), 27-41.

Ningtyas, F., \& Nazar, M. R. (2016). Pengaruh Persepsi Manfaat, Kemudahan, Kerumitan, dan Sikap Penggunaan Terhadap ERP (studi empiris pada Mahasiswa Akuntansi FEB Universitas Telkom).

Perangin-angin, W. A., Respati, A. D., \& Kusumawati, M. D. (2016). Pengaruh Perceived Usefulness Dan Perceived Ease of Use Terhadap Attitude Toward Using E-Faktur. Jurnal Riset Ekonomi Dan Manajemen, 16(2), 307. https://doi.org/10.17970/jrem.16.1602010.id

Prabawalingga, i gusti ngurah mayun, \& Yadnyana, i ketut. (2016). Persepsi Kemanfaatan dan Persepsi Kemudahan dengan Minat Penggunaan sebagai Variabel Intervening terhadap Perilaku Penggunaan Sistem. E-Journal Ekonomi Dan Bisnis Universitas Udayana, 5(10), 3359-3390.

Pratama, A. B., \& Suputra, I. D. G. D. (2019). Pengaruh Persepsi Manfaat, Persepsi Kemudahan Penggunaan, dan Tingkat Kepercayaan Pada Minat Menggunakan Uang Elektronik. E-Jurnal Akuntansi, $27, \quad 927$. https://doi.org/10.24843/eja.2019.v27.i02.p04

Putra, A. A. S., Suprapti, N. W. S., Yasa, N. N. K., \& Sukaatmadja, I. P. G. (2019). Technology Acceptance Model and Trust in Explaining Customer Intention To Use Internet Banking. Russian Journal of Agricultural and Socio-Economic Sciences, 91(7), 254-262. https://doi.org/10.18551/rjoas.2019-07.29

Rithmaya, C. L. (2016). Pengaruh Kemudahan Penggunaan, Kemanfaatan, Sikap, Risiko Dan Fitur Layanan Terhadap Minat Ulang Nasabah Bank Bca Dalam Menggunakan Initernet Banking. Jurnal Riset Ekonomi Dan Manajemen, 16(1), 160. https://doi.org/10.17970/jrem.16.160110.id

Rusfianto, M., Widiartanto, \& Prabawani, B. (2016). Pengaruh Persepsi Manfaat, Kemudahan Penggunaan, Dan Kepercayaan Terhadap Sikap Penggunaan Layanan Internet Banking (Studi Komparasi Pada Nasabah Pengguna Internet Banking Bank Mandiri Semarang Berdasarkan Tingkat Pendapatan). 1989. https://ejournal3.undip.ac.id/index.php/jiab/article/viewFile/11315/10972

Salimi, M., Pourdarbani, R., \& Nouri, B. A. (2020). Factors Affecting the Adoption of Agricultural Automation Using Davis's Acceptance Model (Case Study: Ardabil). Acta Technologica Agriculturae, 23(1), 30-39. https://doi.org/10.2478/ata-2020-0006

Salsabila, D. V. (2016). Pengaruh Kemudahan Penggunaan Dan Kemanfaatan Terhadap Sikap Pengguna Sistem Informasi Akademik Mahasiswa. Jurnal Administrasi Bisnis (JAB), 36(1), 51.

Umamah, faroh fahriyatul, \& Pribadi, joni dwi. (2006). Kegunaan Terhadap Sikap Perilaku Penggunaan Aplikasi. Jurnal Aplikasi Bisnis, 17-20.

Widarto, E., Shanti, \& Tedjasuksmana, B. (2013). Faktor-Faktor Yang Mempengaruhi Kemauan Untuk Membayar Pajak Pada Usaha Mikro, Kecil, Dan Menengah (Studi Kasus Pada Usaha Mebel Di Klaten). Fakultas Ekonomi Dan Bisnis Universitas Muhammadiyah Surakarta, 1-16.

Wong, K. T., bt Osman, R., Goh, P. S. C., \& Rahmat, M. K. (2013). Understanding 
student teachers' behavioural intention to use technology: Technology acceptance model (TAM) validation and testing. International Journal of Instruction, 6(1), 89-104.

Wulandari, P. A., \& Iryanie, emy. (2018). Pajak Daerah Dalam Pendapatan Asli Daerah. Deepublish. 